\title{
Process Matters: Petitions Systems in Britain's Legislatures
}

Catherine Bochel

Reader in Policy Studies

School of Social \& Political Sciences

University of Lincoln

Brayford Pool

Lincoln

LN6 7TS

Tel: 01522886324

Email: cbochel@lincoln.ac.uk

\section{Acknowledgements}

This work was supported by the British Academy under Grant SG101961.

I am grateful for the comments of the anonymous reviewers. 


\begin{abstract}
Over the past fifteen years petitions systems have become embedded in the Scottish Parliament and the National Assembly for Wales, and more recently the House of Commons. This article uses the concept of procedural justice, with its emphasis on the fairness of the process by which decisions are made, as an analytical tool to explore four case studies of petitions systems in British legislatures, considering, in particular, the extent to which they enable voice, decision making and transparency. It illustrates that the application of ideas of procedural justice not only provides us with a useful tool for analysing petitions systems in representative political institutions, but also potentially provides a framework of ideas from which petitions systems, and perhaps other participatory initiatives, may learn.
\end{abstract}

\title{
Keywords
}

Legislatures, participation, petitions systems, procedural justice, transparency, voice. 


\section{Introduction}

Notions of procedural justice, with its focus on fairness of process, have been used in a variety of fields, including psychology, law and business. This article applies procedural justice as an analytical tool to study a number of petitions systems in legislative bodies in the United Kingdom.

The Wright Committee (House of Commons Reform Committee, 2009) and the subsequent inquiry into the impact of the Wright reforms (House of Commons Political and Constitutional Reform Committee, 2013) highlighted the need for greater public engagement with Parliament, with the Wright Committee (p. 69) recognising that 'the only more or less direct means for those outside the House to initiate proceedings is through petitions'. While petitions are not a new form of participation (indeed the first known petitions to the Houses of Parliament date back to the reign of Richard II, and developed over time from matters dealing with 'personal or local grievances' to those of public policy (House of Commons Information Office, p. 6, 2010)), petitions systems have come to prominence in the UK in recent years, with paper and e-petitions systems being established in the Scottish Parliament (in 1999 and 2004, respectively), and in the National Assembly for Wales (in 2007 and 2008). In 2006 the Labour government set up the 10 Downing Street system, which the Coalition government replaced in 2011 with an e-petitions system which straddled the Whitehall/Westminster divide (Bochel, 2013; Fox, 2012). In 2015 that, in turn, was replaced by a collaborative UK government and Parliament system (House of Commons Procedure Committee, 2014). A number of local authorities also have petitions systems in place. The systems receive significantly different numbers of petitions, with, for example, the Scottish Parliament and the National Assembly for Wales' Petitions Committees receiving 185 and 115 respectively in the 2014/15 session (Scottish Parliament Public Petitions Committee, 2015 , p. 36). The Coalition's e-petitions system received 60,818 over the period from July 2011 to March 2015 (http://epetitions.direct.gov.uk/petitions, accessed 23/03/2015) and the collaborative UK government and Parliament system set up in July 2015 had received 9,121 by April 2016 (https://petition.parliament.uk/petitions, accessed 29/04/2016). All of these figures include both admissible and inadmissible petitions (see individual petition system websites for more detail on admissibility criteria) and the figures cited here are intended to be illustrative of differences in scale.

There is, therefore, a recognition by formal representative institutions of the popularity of petitions with the public, and for allowing them to express their views, but at the same time the introduction of such systems has not been unproblematic. In particular, there is likely to be a gap between aspiration and reality for petitioners, because the vast majority of people who submit a petition to an elected representative institution are not going to get what they ask for. In 2013, Natascha Engel, then chair of the Backbench Business Committee, giving evidence to the Political and Constitutional Reform Committee on the Coalition government's e-petition system, noted that expectations had been raised that if an e-petition reached 100,000 signatures, not only would there be a debate, but there would be a vote and a change in the law immediately the petition achieved the $100,000^{\text {th }}$ signature, stating, 'That is obviously not true and is not something that we can deliver, but that is what the public perception is. I think that has been quite damaging' (House of Commons Political and Constitutional Reform Committee, 2013, para. 121).

As a result, petitioners' experience of, and treatment by these systems is important. It may affect how they view not only the petitions systems, but also the elected bodies that establish 
them as a tool for public engagement, and potentially the wider political and governmental processes. Carman, referring to the Scottish Parliament's Public Petitions Committee (2010, p. 736), argues, 'If advocacy reforms are to foster, in any meaningful way, a participatory political culture and connect the public with governing institutions, then those individuals who do engage with the advocacy reforms must see the process by which these reforms work as politically neutral and potentially influential. This is due to the nature of advocacy reforms which reserve the final decision-making authority to the parliament'.

This importance of process is underlined by Fox (2009, p. 682), who notes that 'The public's desire for influence rather than involvement, for giving voice to their views and being heard, points to the fact that the political process may be as important as policy outcomes from any such process'.

\section{Methodology}

This article uses procedural justice as an analytical tool to explore four case studies (Burnham, et al., 2008; Van Theil, 2014; Yin, 2014) of petitions systems: the paper and epetitions systems in the Scottish Parliament and the National Assembly for Wales, the epetitions system introduced by the Coalition government, and the recently established collaborative UK government and Parliament system. The research demonstrates that three of the four systems considered here can be seen to take an approach that reflects the 'system' characteristics of procedural justice to different degrees.

The case studies were selected to reflect systems at the national and devolved levels. The inclusion of the UK government and Parliament system, whilst new at the time of writing, is useful, since it suggests that the importance of 'process', as reflected in some of the 'system' characteristics of procedural justice, has been recognised in the transition from its predecessor. It is also illustrative of a developmental process, which, in part, is also evidenced by a number of select committee inquiries that have sought to address some of the issues around public engagement and the utility of petitions systems (House of Commons Political and Constitutional Reform Committee, 2013; House of Commons Procedure Committee, 2014).

In addition to the review of the literature the research involved collecting data on each system using a variety of sources, such as the information available on websites, correspondence and telephone calls with clerks, observations of petitions committee meetings where relevant, and in-depth interviews with 33 MSPs, AMs, MPs, and clerks. This enabled an in-depth picture of each system to be built up. A number of the clerks were interviewed more than once because they were an important source of information on the systems, and repeat interviews were an important way of keeping abreast of developments. This approach also enabled the triangulation of findings, including, for example, whether what was being said in interviews with members and clerks was happening in practice. Quotes from interviewees are largely anonymised in the text, although in a number of instances they were happy to be quoted. The legislature is identified in each case.

The article first considers what procedural justice is, identifying its main characteristics to set out a basic framework; secondly, it focuses on the 'system' characteristics of procedural justice and considers the extent to which they are reflected in the different petitions systems; finally, it discusses what ideas of procedural justice might have to offer petitions systems. 


\section{What is procedural justice?}

The importance of administrative procedures, and consequently of procedural justice, is widely recognised. Rusch, for example, (2009, cited in Harlow and Rawlings, 2014, p. 2) highlights the need for 'a pre-established decision-making procedure..., which is particularly crucial if the organisation deals with public interests'. Procedural justice is also linked to legal and constitutional debates, both historic and current (see, for example, Craig, 2012). As a concept, therefore, it has relevance to organisations such as representative political institutions, but it is also very wide ranging in nature.

For the purposes of this article procedural justice is concerned with: the fairness of the process by which decisions are made, and the role participants may have in this. It draws on theories of procedure which have been applied to a variety of different fields, including law (for example, Harlow and Rawlings, 2014; Craig, 2012; Thibaut \& Walker, 1975, 1978); psychology (for example, Blader \& Tyler, 2003; Folger, 1977; Lind et al., 1990); business and management (for example, Groth \& Gilliland, 2001; Maguire \& Lind, 2003); political science (for example, Carman, 2010; Grimes, 2006); social policy (for example, Riddell, 2003) including healthcare resource allocation (Tsuchiya et al., 2005); and criminology (for example, Hough et al., 2010). It encompasses a range of ideas and characteristics as discussed below.

It is important to recognise that there are different theories of procedure, and that authors, including those discussed here, define procedural justice and its components in differing ways. Blader and Tyler (2003, p. 747) define procedural justice as a 'fair' process. Thibaut and Walker (1975), in an early study, sought to apply social psychological insights to the United States' legal system. They developed a control model concerned with the level of participation or voice that procedures allow. Lind and Tyler (1988) later created an alternative model based on relational concerns, such as 'status recognition, trust in the benevolence of authorities, and neutrality' (Tyler, Degoey \& Smith, 1996, cited in Blader \& Tyler, 2003, p. 748). This draws attention to the importance of non-instrumental concerns in making judgements about the legitimacy of authorities, including recognising that 'process' itself has some intrinsic value. Whilst it is recognised that fairness judgements may be driven by instrumental 'self-interest' concerns, for example in respect of positive outcomes, it can be argued that 'the primary impact of experience on views about the overall legitimacy of authorities involves judgements about how one is treated, not judgements about gain or loss' (Tyler, 1997, p. 326). Blader and Tyler (2003) highlighted four components, two of which are appropriate here, the quality of decision making and the quality of treatment, to explore the meaning of procedural fairness. A variety of characteristics have been associated with procedural fairness, so that Tyler (1994, cited in Murphy-Berman, Cross \& Fondacaro, 1999, p. 118) sees 'trust and dignity' as important in the evaluation of procedural fairness, Paavola and Adger highlight 'Recognition, participation and legitimacy' (2002, p. 2), Maguire and Lind (2003, p. 134) include 'voice', being treated with 'respect', 'fair treatment', 'decisions that are responsive to information and that are correctable in the face of new information', and 'a perceived lack of bias on the part of authorities', and Tsuchiya et al., (2005, p. 119) list 'accuracy; consistency; impartiality; reversibility; transparency; and voice'.

Drawing on the literature above, the key characteristics underpinning interpretations of procedural justice can be seen to broadly include: voice (and participation); decision making; 
transparency; treatment; legitimacy; and trust. The first three of these might be termed 'system' characteristics, because the parameters are effectively established by the individual systems. They can be explored by researching the ways in which the individual systems operate and the processes underpinning them, and might be seen as the primary indicators of procedural justice. Treatment, legitimacy and trust are different because they are judgements on the 'system' characteristics, which might be considered, for example, through interviews with petitioners and observations of their treatment by clerks and members. They might be termed 'perception' characteristics.

The views of petitioners (their judgements on the 'system' characteristics) on the processes, and how these affect their ability to engage with and views of political institutions are useful, and potentially important. However, it is primarily the boundaries that are set by the processes in place in each system that are likely to facilitate, or hinder, the extent of procedural justice. This article therefore focuses on the 'system' characteristics of procedural justice to see whether these ideas can provide a framework with which to analyse petitions systems, and if so, what we might learn from this.

A basic framework of possible measures of the system characteristics of procedural justice is set out in Figure 1. There is, perhaps inevitably, some overlap in terms of the measures, so that, for example, the actions that petitions committees can take could be used as a measure of all three system characteristics, as is apparent from the discussion that follows.

Figure 1: Measuring the system characteristics of petitions systems

\begin{tabular}{|c|c|}
\hline $\begin{array}{l}\text { System } \\
\text { characteristics of } \\
\text { procedural justice }\end{array}$ & Possible measures \\
\hline $\begin{array}{l}\text { Voice and } \\
\text { participation - the } \\
\text { degree of voice or } \\
\text { participation that the } \\
\text { individual systems } \\
\text { allow. }\end{array}$ & $\begin{array}{l}\text { Whether all petitions are considered in some meaningful manner. } \\
\text { Whether petitioners receive a specific response to their petition. } \\
\text { Whether the system provides further opportunities for voice, for } \\
\text { example through opportunities to present information to a petitions } \\
\text { committee or taking part in a debate. } \\
\text { Whether there are roles for petitioners in the petitions process. } \\
\text { The actions that petitions committees can take. } \\
\text { The role of clerks and petitions committees in assisting with the } \\
\text { presentation of the petition. } \\
\text { The committees doing some of their work outwith the } \\
\text { parliament/assembly. }\end{array}$ \\
\hline $\begin{array}{l}\text { Decision making - } \\
\text { encompasses: } \\
\text { control over decision } \\
\text { making; } \\
\text { control over the } \\
\text { process; }\end{array}$ & $\begin{array}{l}\text { Control over decision making (decision control): } \\
\text { the extent to which there is direct control by elected } \\
\text { members. } \\
\text { Control over the process (process control); } \\
\text { through planning, gathering and selecting information to put } \\
\text { together a petition; }\end{array}$ \\
\hline
\end{tabular}




\begin{tabular}{|l|c|}
\hline $\begin{array}{l}\text { and the quality of } \\
\text { decision making. }\end{array}$ & \multicolumn{1}{c|}{$\begin{array}{c}\text { having the opportunity to respond to evidence collected. } \\
\text { The quality of decision making: } \\
\text { the accuracy, consistency, impartiality, reversibility, and } \\
\text { responsiveness of decisions; } \\
\text { the actions that petitions committees can take. }\end{array}$} \\
\hline $\begin{array}{l}\text { Transparency - the } \\
\text { clarity of the process } \\
\text { for petitioners }\end{array}$ & $\begin{array}{c}\text { The information available to petitioners on: } \\
\text { what they can and cannot achieve by submitting a petition; } \\
\text { the actions committees can take; } \\
\text { the role for petitioners in the process; } \\
\text { potential outcomes; } \\
\text { the help available to petitioners. }\end{array}$ \\
& $\begin{array}{l}\text { The openness of the decision making process - are meetings } \\
\text { conducted in public, minutes available, etc. }\end{array}$ \\
\hline
\end{tabular}

\section{The system characteristics of petitions systems}

This section analyses the system characteristics of the four systems. The systems in the Scottish Parliament and the National Assembly for Wales are the longest established, and have much in common from a procedural justice perspective, including having been underpinned by attempts to develop more open and transparent processes in the new legislatures (McAllister, 2000; Mitchell, 2000), and in order to avoid repetition they are therefore considered together, although, where relevant, examples from the different systems are provided. In addition, as illustrated earlier, those systems receive considerably fewer petitions than the Coalition or the UK government and Parliament systems. This may affect the numbers of petitions (and hence petitioners) that they can give a voice to, but it does not affect the primary focus of this article, the processes that have been set up by the systems that might enable (or otherwise) voice and participation, decision making and transparency. In contrast, at the time of writing, the collaborative UK government and Parliament system had been established for only nine months. However, it too appeared to have adopted an approach which reflects some of the characteristics of procedural justice, in part because of a recognition of some of the shortcomings of the Coalition government's e-petitions system, and it has drawn lessons from the systems in the devolved legislatures which are widely perceived to be models of good practice, as illustrated below.

The following section considers the extent to which the system characteristics of procedural justice can be evidenced in the case study systems using the measures outlined in Figure 1.

\section{Voice and participation}

The devolved legislatures

The Scottish Parliament's Public Petitions Committee and the National Assembly for Wales Petitions Committee discuss all admissible petitions. At a minimum, therefore, petitioners are able to get their issues on the agenda and have them discussed. Their voices are therefore to 
some extent being heard, and, as they all receive a specific response to their petition, they are aware of this, while those inside the systems recognise the importance of this. The Chair of the Petitions Committee in the National Assembly for Wales noted, 'People feel listened to, people are able to tell their story' (Int. NAW01). Another member of the Committee noted, 'People are always really encouraged that you have taken them seriously even if they don't get what they want, they see it as a positive process and get their views considered. Great for democracy' (Int. NAW03). An MSP talked about how petitioners feel they have been treated: 'Petitioners often feel that they have had a hearing and understand even if they don't get the outcome they want' (Int. SP06).

In some cases, usually where the issue has wider public interest, petitioners have the opportunity to present their information to the petitions committee, or to take part in a roundtable discussion, which provides them with additional opportunities for 'voice' (see, for example, Tsuchiya et al., 2005). Lane (1988, cited in Lind et al., 1990, p. 952) underlines the importance of this when he describes 'the opportunity to be heard as a 'dignity good' that citizens value in government procedures', whilst Lind and Tyler (1988) highlight relational concerns such as 'status recognition' as also playing a role here.

The input from the clerks and petitions committees in terms of assisting with the presentation of the petitioner's case may also help to ensure that petitioners' voices are heard. For example, a Committee official in Wales noted, 'the majority of petitioners talk to the clerking team' (Int. NAW02) in advance of submitting a petition in order to try ensure that the wording of their petition is clear. In addition, the collection of information from other organisations by the clerks in order that the committee have available the appropriate information on which to base a decision, may also have further impacts in relation to voice.

Voice may also be improved by the range of actions available to the committees in their decision making, which, while it can involve closing petitions and taking no further action, can also progress topics within the legislatures and pursuing issues with the governments and other organisations, sometimes with the involvement of petitioners. As one MSP commented, we 'have also held roundtable discussions for petitioners, government ministers and organisations' (Int. SP06). In Wales, following a petition by Tenovus, a Welsh cancer research charity, asking the Welsh Assembly Government to provide free sunscreen for children, the Petitions Committee passed this to the Children, Young People and Education Committee, which agreed to undertake a short inquiry into sun protection policy and to produce a report on the issue (P-04-337). Similarly, in both legislatures the committees can initiate debates, as with the noise created by windfarms (petition P-04-239) in Wales and a petition calling for an opt-out system of organ donation in Scotland (PE01453). Committee members also take the view that 'the fact that it comes from the Petitions Committee gives it additional weight, there is extra impetus to find time in the timetable to look at it' (Int. NAW06).

Other elements of the work of the committees may also be important in facilitating or obstructing elements of procedural justice, and perceptions of it. The committees can, for example, be seen to have attempted to facilitate 'voice' by doing some of their work outside Edinburgh and Cardiff, such as a meeting of the Scottish Parliament's Public Petitions Committee held in Stornoway in relation to a petition on Access to Insulin Pump Therapy (PE01404), and a petition by Barnardo's on Tackling Child Sexual Exploitation in Scotland (PE01393) that involved a fact-finding visit by some members of the Public Petitions Committee to Barnardo's in Glasgow. Similarly, in Wales, a petition (P-04-329) on noise 
nuisance from wind turbines during anti-social hours led the Committee to hold an open meeting in Carmarthen to enable as many people to express their views as possible. Initiatives such as these at least suggest the possibility for a degree of voice, and indeed additional voice for some petitioners, in these systems.

\section{The Coalition government's e-petitions system}

The large number of petitions received by this system meant that it was not feasible that all petitions be considered. It did provide the opportunity for voice through eligibility for a debate in the House of Commons on the issue if a petition achieved 100,000 signatures, although simply reaching the threshold was no guarantee of this. At that stage petitions were passed to the Backbench Business Committee to see if any MP was willing to sponsor a debate on the issue raised in the petition. If an MP was willing to do so, and if the Backbench Business Committee had been allocated sufficient time to schedule a debate, then it would proceed. In those cases the petitioners arguably exercised a greater degree of voice, because they got their issue on the agenda and had it debated, although there was no role for the petitioners themselves in this. In total, 37 petitions received more than 100,000 signatures over the period that the system was in operation from late summer 2011- spring 2015, and 32 of those were debated in some form.

In September 2012 a 10,000 signature threshold was added. At that threshold petitioners received a general response from the relevant government department. These tended to set out the government's position on the issue, rather than providing a specific response to the issue raised in the petition. However, 97.7 per cent of petitions (Fox, 2012) received fewer than 1,000 signatures.

In this system there was also a limited role for clerks in assisting with the presentation of petitions, so that, as a report by the Backbench Business Committee noted, 'There is no telephone helpline or email advice service; and, as a result, when people sign an e-petition, their expectations cannot be managed' (House of Commons, Backbench Business

Committee, 2015, para. 57). Members of the public could contact the clerk of the House of Commons paper system for advice if they wished, although this avenue of support was not well advertised.

For the vast majority of petitioners, therefore, the processes provided, at best, an extremely limited opportunity for voice through using the system as a way of seeking to communicate their views to government or Parliament. As a report by the Hansard Society noted, 'It is a very thin form of public engagement - predicated solely on quantity not quality and is almost entirely one-directional' (Fox, 2012, p. 9).

The UK government and Parliament system

The system that replaced the Coalition government's system can be seen to provide greater opportunities for voice. As with its predecessor, there are particular types of outcome associated with specific signature thresholds, and, for example, twenty-four debates in the House of Commons had taken place between the establishment of the system in July 2015 and the end of April 2016. However, a major difference lies in the creation of a dedicated Petitions Committee and its ability to take a variety of actions. The Petitions Committee considers all petitions that reach the 10,000 and 100,000 signature thresholds, not in terms of 'the merits (mostly) of what is asked for, but whether the subject is being considered 
elsewhere in Parliament, and whether the Government has provided a proper response' (correspondence with Committee official). For example, it 'can correspond with petitioners on their petition; call petitioners for oral evidence; refer the petition to the relevant select committee; seek further information from the Government, orally or in writing, on the subject of a petition; and put forward petitions for debate (House of Commons Procedure Committee, 2014, p. 3). These mirror many of the processes in the Scottish Parliament and the National Assembly for Wales systems. Indeed, even petitions that are rejected may still have some opportunity for voice, so that, for example, if a petition duplicates an existing petition, petitioners are told that they may stand a better chance of getting action on the issue if they sign and share a single petition, and are provided with a link to the existing petition.

Similarly, if it is not clear what the petition is asking for, petitioners are informed that if they provide a clearer request for action, it could be looked at again. And where the subject is something the UK government and Parliament is not responsible for, the petitioner may be given suggestions for the most appropriate organisation to contact. The latter is also the case in the devolved legislatures. The Committee has also undertaken a variety of other activities, such as writing to the government, for example, asking to be informed when a final NICE guidance report is published, so that it can inform the petitioners for the 'We need Jeremy Hunt MP to get NHS England to fund Vimizin for Morquio Sufferers' petition, and 'tagging' (identifying as a relevant document) the petition 'The Cancer Drug Fund (CDF) is not fit for purpose and needs to be replaced', to a debate on the availability of cancer drugs in Westminster Hall and notifying the petitioners about the debate. It also forwards petitions to relevant select committees, and the Women and Equalities Committee took evidence from a petitioner who had initiated a petition to 'Allow transgender people to self-define their legal gender' because it was relevant to their inquiry into transgender equality.

The processes in place provide opportunities for some degree of voice, and a limited additional role for some petitioners, and the clerks and the Committee can be seen to be facilitating this through their working methods and flexible approach.

\section{Decision making}

Thibaut and Walker (1978, p. 546) discuss the different elements that make up 'control' for participants, including 'control over the decision and control over the process', and suggest that:

\footnotetext{
'Decision control is measured by the degree to which any one of the participants may unilaterally determine the outcome of the dispute... Control over the process refers to control over the development and selection of information that will constitute the basis for resolving the dispute. Participants given authority to conduct an investigation and to plan the presentation of evidence may be said to exercise considerable process control' (Thibaut \& Walker, 1978, p. 546).
}

Decision making by the systems (clerks, elected members) links with other characteristics of procedural justice, such as transparency, in that if the ways in which the systems operate are transparent, then such systems may exhibit some of characteristics of procedural justice. In petitions systems decision control clearly rests with elected representatives, and petitioners do not have any direct role in this. However, petitioners may have scope for limited control over some elements of the process, as discussed below. 
For some petitioners there may be the opportunity to have some influence over the process because they are kept fully informed of progress on their petition, given copies of any responses received from other organisations, and have the opportunity to respond to the evidence gathered. One MSP commented, 'The clerks contact petitioners with the responses received from organisations. They have input at every stage' (Int. SP03). Another said, 'We write to a wide range [of organisations] including voluntary organisations, third sector organisations, etc. The responses can be fairly detailed... The Public Petitions Committee has to put all the responses together. All responses are explored i.e. the petitioner can challenge or respond to the responses provided. This creates a detailed dialogue' (Int. SP06). This fits with Maguire and Lind's (2003, p. 134) identification of 'decisions that are responsive to information and are correctable in the face of new information', both factors identified as potential measures of the quality of the decision making process. The quality of decision making may also be improved by the greater range of actions available to the Committees in their decision making, as noted in the consideration of voice.

This indicates that attempts are made to provide a sound basis on which to make decisions relating to petitions. It also means that petitioners have a small degree of process control, in that they can plan, gather and select information on the issue they wish to petition on, and, reflecting the role of the clerks noted in the discussion of voice above, they may be guided by a clerk in this, which may enable them to gather further information on the issue raised and to put together a stronger case for their petition. The status of the legislatures can also be seen as having some potential to empower some petitioners, with a Welsh Assembly member highlighting the Petitions Committee being able to write to organisations and perhaps getting a more detailed response for petitioners than might otherwise be the case (Int. NAW05), while the Convenor of the Public Petitions Committee in the Scottish Parliament noted, 'We are more likely to open a door than a petitioner when writing to organisations' (Int. SP05).

\section{The Coalition government's e-petitions system}

Unlike the other systems considered here, there was no Petitions Committee and no dedicated clerk for this system, although the clerk to Petitions for the House of Commons paper system did deal with queries from petitioners. As noted in the discussion above, there was also no real decision making in the system, at least until petitions were passed to the Backbench Business Committee at the 100,000 signature level. At that stage MPs had to decide whether to debate the petition, and if so whether the debate should be on the topic of the petition or a more general debate that broadly addressed the issue raised. Decision control therefore rested with elected representatives. It was only in planning, gathering and selecting information on the issue that petitioners were able to exert a very small degree of control over the process.

\section{The UK government and Parliament system}

In this system, direct control over decision making again rests with elected members, although some petitioners may have an opportunity for a degree of control over the process through the Committee corresponding with them on their petition. For example, a Committee official said, 'people do come back with redrafted petitions in response to the guidance we give them', and the Committee has a collection of emails with petitioners illustrating this process (correspondence with Committee official). As in the other systems, petitioners also have some limited degree of process control in that they plan, gather and select information 
on the issue they wish to petition on, and, in contrast with the previous system, help and advice is available from the clerks, which may enable people to put together a stronger case in their petition. A small number are also called to give oral evidence to the committee, as, for example, with the petition, 'Fund more research into brain tumours, the biggest cancer killer of under 40s'. As with the devolved legislatures, the quality of decision making may also be improved by the greater range of actions available to the Committee in its decision making.

\section{Transparency}

Transparency in the individual systems is largely achieved by clarity of the variety of processes involved in submitting petitions, the potential outcomes, and the decisions made (see Figure 1). Consideration of these is by its very nature largely descriptive. The discussion below therefore seeks primarily to highlight some of the main differences between the systems.

The devolved legislatures

The Scottish Parliament and the National Assembly for Wales present their petitions systems to petitioners in an open and transparent way, with a clear attempt to manage expectations so that petitioners know what they can and cannot achieve. For example, the website of the Petitions Committee in Wales has a Video: A Guide to National Assembly for Wales Petitions (http://www.assemblywales.org/gethome/e-petitions.htm, accessed 27/01/2014), which sets out the formal process of submitting a petition. This includes: the actions the Petitions Committee can take, what petitioners can achieve, including 'give petitioners the opportunity suggest changes to Welsh Government policy or suggest new laws, raise the profile of an issue which may not previously have been on the political agenda, ... gather further information on the issue from the Welsh Government and other relevant bodies'; and the role petitioners can play in this process, including being invited to give evidence to the Committee on their petition.

Similarly, in Scotland the principal means for providing information on the petitions system is the Parliament's website, which gives petitioners detailed information in a variety of formats. A video of petitioners talking about their experience of the process highlights the role petitioners can have in the process, and at the same time may serve to inspire confidence in the process so that petitioners can feel that they and their issue will be taken seriously. A Committee official commented, 'All petitions are handled fairly and openly. You may not be happy with the outcome but do not confuse this with process' (Int. SP07). Indeed, one MSP noted that, 'There was one session on the Public Petitions Committee where two former petitioners gave a talk in order to highlight the process to the audience' (Int. SP06).

In both systems petitioners can attend meetings of the Committees in person to listen to the discussion of their petition, or they can watch them online. The Convenor of the Public Petitions Committee in the Scottish Parliament said, 'We believe in being open. There are no discussions in private. All our meetings are live, all are recorded' (Int. SP05).

The Coalition government's e-petitions system 
The e-petitions website provided some information on 'how e-petitions work' (http://epetitions.direct.gov.uk/how-it-works\#commons, accessed 12/05/2014) including the statement that:

'e-petitions are an easy, personal way for you to influence government and Parliament in the UK. You can create an e-petition about anything that the government is responsible for and if it gets at least 100,000 signatures, it will be considered for debate in the House of Commons' (http://epetitions.direct.gov.uk, accessed 17/12/2013).

This was arguably misleading, as highlighted by the quote from the chair of the Backbench Business Committee, Natascha Engel, in the introduction to this article. Indeed, in explaining the process for those petitions that reached that threshold in a short video, she also attempted to manage expectations by explaining that the scheduling of e-petitions for debate was dependent on the Committee being allocated time by the government. At that stage there was, therefore, an attempt by Parliament to achieve a greater degree of transparency in relation to the process by which decisions were made, although this was only partial, and there was no role for petitioners in this. In addition, the system did not explain to petitioners that they would not get any response to their petition if it received fewer than 10,000 signatures, while those that reached this threshold would receive a response from the relevant government department, which was published online.

So, from a procedural justice perspective, the process by which decisions were made was not particularly transparent because it was not clearly communicated to petitioners, other than if a petition reached the 100,000 threshold, although even then its potential impact was exaggerated, and the reality was that very few, if any, petitions were likely to be able to influence the policy making process.

The UK government and Parliament system

The petitions website (https://petition.parliament.uk/) sets out a range of information on the process. This is supplemented by the Petitions Committee website (http://www.parliament.uk/business/committees/committees-a-z/commons-select/petitionscommittee/), which provides information on the work of the Committee including how it makes its decisions, decisions on petitions, including inquiries and debates, guidance on what debates can achieve, and Government responses to petitions with over 10,000 signatures. All debates in Westminster Hall are open to the public, and can also be watched online, and although meetings of the Committee are conducted in private, minutes are published.

The Petitions Committee undertook a consultation on working methods shortly after it was established. Responses were published on the Committee's website and a short report was due to be published at the time of writing. In addition, the Committee held an event for campaigners to learn about the new system, intended to have an educative function and to help petitioners make their petitions as effective as possible and to understand what they could achieve.

Overall, the new system appears to be operating in an open and transparent manner with clear information available to the public, and to reflect the system characteristics of procedural justice to a significantly greater degree than its predecessor. 


\section{Conclusions}

This article uses procedural justice as an analytical tool to explore four case studies of petitions systems. In setting out the key characteristics of procedural justice, it has identified two different types: 'system' and 'perception'. The former are the focus of this article, because the parameters of these are effectively established by the systems, and it is the processes that the systems have put in place that are likely to facilitate, or hinder, the extent of procedural justice. The latter are effectively judgements on the 'system' characteristics, and whilst these may be important they do not affect the extent to which the systems can be seen to facilitate a procedural justice approach.

The parameters established by the individual systems, and how these are set out, is clearly a major influence on the extent to which they reflect the 'system' elements of procedural justice: voice, decision making and transparency. The discussion above highlights that while power over decision making in all of the systems considered here is ultimately retained by elected representatives, it is possible to identify different degrees of opportunity for voice, and to a more limited extent for influence over decision making and the process of decision making, with those systems that have established petitions committees, provide support for petitioners in developing their petitions, and which are able to take a variety of actions, notably, the systems in the Scottish Parliament, the National Assembly for Wales and the UK government and Parliament, offering a greater degree of procedural justice than the Coalition government's system. This highlights some convergence in the approaches of the devolved legislatures and the UK government and Parliament systems, with the latter having drawn on the experience and practice in the systems in Scotland and Wales. In addition, it is clear that it is possible to achieve relatively high levels of transparency for petitioners through the provision of clear information on all aspects of the petitions process.

Petitions systems appear to be becoming a more established part of the parliamentary process, and can play a role in contributing to representative democracy (Bochel, 2013). As the systems become more embedded, so the relationships between the petitions committees, other committees and government departments are likely to become even more important in relation to the processes that they adopt and the effectiveness of the systems.

Overall, the application of ideas of procedural justice to representative political institutions not only provides us with a useful tool for analysing petitions systems, but also potentially provides a framework of ideas from which petitions systems, and perhaps other participatory initiatives, may learn. This is significant because petitions are clearly popular with the public as a method of engaging with elected bodies, as illustrated by the quantity of petitions submitted to each body and the numbers who sign them. They can also achieve a range of different outcomes (Bochel, 2012). However, given that most people who petition are not going to get what they ask for, their experience of, and treatment by the various systems is very important, and reinforces the view of Fox (2009, p. 682) in the introduction to this article 'that the political process may be as important as policy outcomes'.

\section{Author note}

Catherine Bochel is a Reader in Policy Studies at the University of Lincoln, email: cbochel@lincoln.ac.uk 


\section{References}

Bochel, C. (2013). Petitions systems: Contributing to representative democracy? Parliamentary Affairs, 66, 798-815.

Blader, S. L., \& Tyler, T. (2003). A four component model of procedural justice: Defining the meaning of a "fair" process. Personality and Social Psychology Bulletin, 29, 6, 747-758.

Burnham, P., Lutz, K., Grant, W., \& Layton-Henry, Z. (2008). Research methods in politics. Basingstoke: Palgrave Macmillan.

Carman, C. (2010). The process is the reality: Perceptions of procedural fairness and participatory democracy. Political Studies, 58, 731-751.

Craig, P. (2012) Administrative Law, London: Sweet \& Maxwell.

Fogler, R. (1977). Distributive and procedural justice: Combined impact of voice and improvement on experienced inequity. Journal of Personality and Social Psychology, 35, 2, 108-119.

Fox, R. (2012). What next for e-petitions? London: Hansard Society.

Fox, R. (2009). Engagement and participation: What the public want and how our politicians need to respond. Parliamentary Affairs, 62, 4, 673-685.

Grimes, M. (2006). Organizing consent: The role of procedural fairness in political trust and compliance. European Journal of Political Research, 45, 285-315.

Groth, M., \& Gilliland, S.W. (2001). The role of procedural justice in the delivery of services. Journal of Quality Management, 6, 1, 77-97.

Harlow, C. and Rawlings, R. (2014) Process and Procedure in EU Administration, Oxford: Hart Publishing.

Hough, M., Jackson, J., Bradford, B., Myhill, A., \& Quinton, P. (2010). Procedural justice, trust and institutional legitimacy. Policing: A Journal of Policy and Practice, 4, 3, 203-210.

House of Commons Backbench Business Committee (2015). Work of the Committee in the 2010-15 Parliament, First Special Report of Session 2014-15. London: The Stationery Office.

House of Commons Procedure Committee (2014). E-petitions: a collaborative system, Third report of Session 2014-15. London: The Stationery Office.

House of Commons, Political and Constitutional Reform Committee (2013). Revisiting Rebuilding the House: the impact of the Wright reforms, Third Report of Session 2013-14. London: The Stationery Office.

House of Commons Information Office (2010) Public Petitions, House of Commons Information Office Factsheet P7, London: House of Commons. 
House of Commons Reform Committee (2009). Rebuilding the House, First Report of Session 2008-09. HC 117, London: The Stationery Office.

Lane, R. E. (1988). Procedural goods in a democracy: How one is treated versus what one gets. Social Justice Research, 2, 177-192.

Lind, E.A., Kanfer, R., \& Earley, P.C. (1990). Voice, control and procedural justice: Instrumental and non instrumental concerns in fairness judgements. Journal of Personality and Social Psychology, 59, 5, 952-959.

Lind, E.A., \& Tyler, T.R. (1988). The Social Psychology of Procedural Justice. New York: Plenum Press.

Maguire, L.A., \& Lind, E.A. (2003). Public participation in environmental decisions: Stakeholders, authorities and procedural justice. International Journal of Global Environmental Issues, 3, 2, 133-148.

McAllister, L. (2000). The new politics in Wales: Rhetoric or reality? Parliamentary Affairs, $53,3,591-604$.

Mitchell, J. (2000). New parliament, new politics in Scotland. Parliamentary Affairs, 53, 3, 605-21.

Murphy-Berman, V., Cross, T., \& Fondacaro, M. (1999). Fairness and healthcare decision making: Testing the group value model of procedural justice. Social Justice Research, 12, 2, 117-129.

Paavola, J., \& Adger, W.N. (2002). Justice and adaptation to climate change. Tyndall Centre for Climate Change Research, working paper 23, School of Environmental Sciences, University of East Anglia.

Riddell, S. (2003). Procedural justice and special educational needs assessments in England and Scotland. International Journal of Inclusive Education, 7, 3, 201-222.

Rusch, W. (2009) 'Administrative Procedures in EU Member States', paper for the OECD/EU SIGMA Conference on Public Administration Reform and European Integration, OECD.

Scottish Parliament Public Petitions Committee (2015) Review of the Petitions Process, $2^{\text {nd }}$ Report, Edinburgh: Scottish Parliament.

Thibaut, J., \& Walker, L. (1975). Procedural Justice. Hillsdale, NJ: Lawrence Erlbaum.

Thibaut, J., \& Walker, L. (1978). A theory of procedure. California Law Review, 66, 3, 541566.

Tsuchiya, A., Miguel, L.S., Edlin, R., \& Wailoo, A. (2005). Procedural justice in public healthcare resource allocation. Applied Health Economics and Health Policy, 4, 2, 119-127. 
Tyler, T.R. (1997). The psychology of legitimacy: A relational perspective on voluntary deference to authorities. Personality and Social Psychology Review, 1, 4, 323-345.

Tyler, T.R., Degoey, P., \& Smith, H.J. (1996). Understanding why the justice of group procedures matters. Journal of Personality and Social Psychology, 70, 913-930.

Tyler, T. R. (1994). Psychological models of the justice motive: Antecedents of distributive and procedural justice. Journal Personality and Social Psychology, 67, 850-863.

Van Theil, S. (2014). Research methods in public administration and public management. London: Routledge.

Yin, R. (2014). Case study research: Design and methods, London: Sage. 